\title{
Coeliac ganglion adrenergic activity modifies ovarian progesterone during pregnancy: its inter-relationship with LH
}

\author{
M Casais, Z Y Sosa, A M Rastrilla and L I Aguado \\ Laboratorio de Biología de la Reproducción (LABIR), Facultad de Química, Bioquímica y Farmacia, Universidad Nacional de San Luis, \\ San Luis (5700), Argentina \\ (Requests for offprints should be addressed to L I Aguado, Universidad Nacional de San Luis, Chacabuco 917, 5.700, \\ San Luis (5700), Argentina; Email: labir@unsl.edu.ar)
}

\begin{abstract}
Most of the fibres that constitute the superior ovarian nerve (SON) originate at the neuronal bodies of the coeliac ganglion and innervate rat ovarian stroma cells. The purpose of this work was to study the part played by innervation on ovarian release of progesterone on day 15 and at the end of pregnancy in an integrated in vitro system known as the coeliac ganglion-SON-ovary system.

We also investigated, in the same system, whether there is some kind of inter-relationship between the effect of adrenergic agents and $\mathrm{LH}$ on progesterone release on day 15 of pregnancy.

The coeliac ganglion and the ovary were incubated in separate compartments, linked by the SON. The ovary was immersed in $2 \mathrm{ml}$ buffer solution (ovarian compartment) and the coeliac ganglion was immersed in $2 \mathrm{ml}$ of a different buffer solution (ganglion compartment). Under these conditions, the accumulation of progesterone in the ovarian compartment medium was used as an endpoint. Conditions were standardised on day 15 of pregnancy, when the decrease in the release of ovarian progesterone caused by non-specific stimulation on the ganglion with $\mathrm{KCl}(56 \mathrm{mM})$ demonstrated the functional integrity of the system. Neural influence was evaluated by the addition of adrenergic agents at a concentration of $10^{-6} \mathrm{M}$ to the coeliac ganglion. On day 15 of pregnancy, noradrenaline and propranolol increased progesterone release while
\end{abstract}

phentolamine diminished it. The existence of ganglionic tone was assessed by analysing progesterone basal levels at different stages of pregnancy. The highest secretion of progesterone was found to take place on day 15, diminishing as pregnancy advanced. In addition, adrenergic neural participation was studied during the physiological luteolysis occurring at the end of pregnancy. Major findings were that noradrenaline increased ovarian accumulation of progesterone on day 19 and decreased it on day 20 , while propranolol and phentolamine diminished progesterone release on both days. In additional studies, some neuroendocrine aspects were investigated at a peripheral level. The addition of LH only to the ovarian compartment did not affect progesterone secretion. However, when LH in the ovarian compartment was accompanied by noradrenaline, propranolol or phentolamine in the ganglion compartment, the release of progesterone decreased.

It can be concluded that modifications of the neural state of the coeliac ganglion affect ovarian progesterone secretion and the physiology of pregnancy via the SON. The results may confirm that the coeliac ganglion-SONovary system provides a direct link between the autonomic nervous system and physiological events during pregnancy.

Journal of Endocrinology (2001) 170, 575-584

\section{Introduction}

Most of the fibres of the superior ovarian nerve (SON) come from the postganglionic sympathetic neurones of the coeliac ganglion and innervate ovarian stroma cells (Lawrence \& Burden 1980, Klein \& Burden 1988). The ovarian cell membranes have adrenergic receptors and their occupation with adrenergic agents modifies the release of ovarian steroids. This fact shows the participation of the peripheral nervous system in ovarian function (Condon \& Black 1976, Coleman et al. 1979, Harwood et al. 1980, Adashi \& Hsueh 1981, Aguado et al. 1982,
Aguado \& Ojeda 1984a,b, Norjavaara et al. 1984, 1989, Sosa et al. 2000). Furthermore, some neurotransmitters that stimulate ovarian progesterone release such as noradrenaline and vasoactive intestinal peptide (Ojeda \& Aguado 1985, Dees et al. 1986, Ojeda \& Lara 1989, Dissen et al. 1993, Gerendai et al. 1995, Kalekzyc et al.1995), or peptides with inhibitory effects such as gonadotrophinreleasing hormone (Hsueh \& Erickson 1979, Huesh \& Jones 1981, Pieper et al. 1981, Sheela Rani et al. 1983) and gamma aminobutyric acid (Erdö et al. 1985, Häppölä et al. 1987) have been found in the ovary. Some of them are also present in the SON and the coeliac ganglion (Jan \& Jan 
1981, 1982, 1983, Sejnowski 1982, Dalsgaard et al. 1983, Karhula et al. 1988, Lascar et al. 1996). In addition, a neural functional connection between different hypothalamic centres and the ovary has been shown to contribute to neuroendocrine regulation (Kawakami et al. 1981, De Bortoli et al. 1998).

In most of the above-mentioned studies, prepuberal, peripuberal, cyclic adults or pseudopregnant rats were used. On the other hand, luteal cells from cyclic rat ovaries or bovine corpus luteum have been shown to cause an increase in progesterone release when they are stimulated with adrenergic agonists (Condon \& Black 1976, Godkin et al. 1977, Zsolnai et al. 1982). In the same way, it has been shown that luteal cells of pseudopregnant rat ovaries respond to catecholamines (Norjavaara et al. 1982, 1984).

However, knowledge about the influence of neural factors on the physiology of gestation is still not clear or sufficiently abundant. Possible reasons for this might be that the response to neural stimulation depends on which stage of pregnancy is being studied, or that the experimental schemes used are not comparable. Harwood et al. (1979) reported that, in spite of having adrenergic receptors in the membranes, the luteal cells from pregnant rats do not respond clearly to adrenergic stimulation. In addition, Lawrence \& Burden (1976) showed that the density of adrenergic fibres in the ovary increased as pregnancy advanced. These authors (Burden \& Lawrence 1977) also found that denervation on days 10, 14 and 18 of pregnancy caused a decrease in the activity of the $\Delta 5-3$ $\beta$-hydroxysteroid dehydrogenase enzyme which synthesises progesterone. However, Roche et al. (1985) who performed the denervation on day 15 observed that it did not affect the normal development of gestation. On the other hand, Massa \& Bruce (1994) have reported that, on day 16 of pregnancy, the secretion of ovarian progesterone is not modified when noradrenaline is injected into the ovarian artery in spite of modifying the arterial pressure. This turns out to be the clearest evidence against the general conception that noradrenaline stimulates ovarian secretion of progesterone during pregnancy.

The aim of the present work was to analyse the adrenergic influence on the physiology of the ovary during pregnancy. The coeliac ganglion-SON-ovary system, previously standardised in our laboratory during the oestrous cycle in rats (Sosa et al. 2000), was used. This scheme does not depend on hormonal influence, and allows study of the adrenergic effect on the sympathetic ganglion and the release of progesterone by the ovary. In addition, the peripheral neuroendocrine inter-relationship between luteinising hormone (LH) and adrenergic agents on day 15 of pregnancy was investigated, using the same coeliac ganglion-SON-ovary scheme. This relationship between LH in the ovary and central (De Bortoli et al. 1998) and peripheral (Sosa et al. 2000) stimulation with adrenergic agents has already been demostrated during the oestrous cycle in our laboratory. Other authors have also proved a local relationship in the ovary between noradrenaline and LH in in vitro systems of isolated cells (Harwood et al. 1980, Jena \& Abramowitz 1989).

\section{Materials and Methods}

\section{Animals}

Pregnant rats bred in our laboratory and originally of the Holtzman strain were used. The rats were kept under controlled conditions, with lights on from 0700 to $1900 \mathrm{~h}$, and at a temperature of $24 \pm 2{ }^{\circ} \mathrm{C}$, with free access to standard rat chow (Cargil SACI; Saladillo, Buenos Aires, Argentina) and water. Vaginal smears were taken daily and only rats with 4-day oestrous cycles were used. Female rats were caged individually with fertile males on the night of the day of pro-oestrus, and the presence of spermatozoa was checked in the vaginal smear the following morning. This day was designated as day 0 of pregnancy. Our colony usually give birth on day 22 .

Groups of six to eight animals on days 15, 19, 20 and 21 of pregnancy were used for each experimental procedure. The experiments were performed in accordance with the Guidelines on the Handling and Training of Laboratory Animals, The Biological Council, UFAW 1992.

\section{Reagents}

The following drugs were purchased from Sigma Chemical Co. (St Louis, MO, USA): L-isoproterenol hydrochloride (Iso), L-D-norepinephrine hydrochloride (NE), L-propranolol hydrochloride (Prop), phentolamine hydrochloride (Ph), HEPES, medium 199, EDTA, collagenase type IV (570 U/mg), dextrose, ascorbic acid, bovine serum albumin fraction V (BSA) and LH. 1,2,6,7$\left[{ }^{3} \mathrm{H}\right]$ Progesterone was provided by New England Nuclear (Boston, MA, USA). Other reagents were of analytical grade. Luteal cells were incubated in 24-well plastic tissue culture dishes (Corning Laboratory Sciences Co., Cambridge, MA, USA).

Surgical procedure and characterisation of the coeliac ganglion-SON-ovary system

The surgical procedure used for removing the system, its characterisation and histological control, as well as standardisation of the incubation times were performed as described previously (Sosa et al. 2000). The system was removed by dissection, avoiding contact between the surgical instruments and the nerve fibres in order to prevent spontaneous depolarisation of the nerves. The piece of tissue removed consisted of the left ovary, the fibres that constitute the SON, inserted in the suspensory ligament, and the coeliac ganglion accompanied by some small ganglia that surround it. The total surgical procedure 


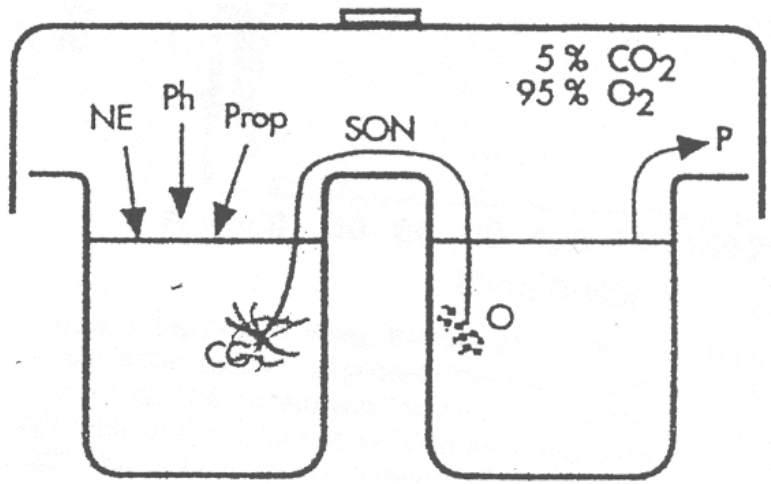

Figure 1 Schematic representation of the cuvette with two compartments for the incubation of the coeliac ganglion-SONovary system. CG, coeliac ganglion; $\mathrm{O}$, ovary; $\mathrm{P}$, progesterone.

was completed in 1-2 min. In order to verify the existence of the ganglion, routine histological techniques were followed throughout the characterisation of the system.

Once the coeliac ganglion-SON-ovary system was removed, it was washed with incubation medium and placed in a cuvette with two compartments. Each compartment contained $2 \mathrm{ml}$ Krebs-Ringer bicarbonate buffer $(\mathrm{pH} 7 \cdot 4)$, with the addition of glucose $(0 \cdot 1 \mathrm{mg} / \mathrm{ml})$ and albumin $(0.1 \mathrm{mg} / \mathrm{ml})$, as has been described for the incubation of ovaries in other in vitro systems (Aguado et al. 1982, Lara et al. 1990a,b, Ferruz et al. 1992).

The coeliac ganglion and the ovary were placed in two separate compartments connected by the SON (Fig. 1). The system was stabilised by preincubation in a metabolic bath at $37^{\circ} \mathrm{C}$ for $30 \mathrm{~min}$ in an atmosphere composed of $95 \% \mathrm{O}_{2}$ and $5 \% \mathrm{CO}_{2}$. The end of the preincubation period was considered as incubation time 0 . At this time, the buffer was changed in both compartments, and periodical extractions were made from the ovarian compartment at 30, 60, 120 and $180 \mathrm{~min}$ for determination of the release of progesterone. Ascorbic acid $(0.1 \mathrm{mg} / \mathrm{ml}$ in Krebs-Ringer) was added as an antioxidant agent to the ganglion compartment at incubation time 0 (Dhariwal et al. 1989, Behrman et al. 1996).

\section{Experimental procedure}

Rats on days 15, 19, 20 and 21 of pregnancy were used. They were anaesthetised with ether and the system was removed by surgery. The fetuses had been previously removed and were killed in an atmosphere of ether. The surgical procedure was performed between 0900 and $1000 \mathrm{~h}$. The coeliac ganglion-SON-ovary system was removed and placed in the above-described cuvette, taking care that the SON was kept moist with the work solution. The values of the progesterone released under these conditions were considered to be the control (control group). For the experimental groups, the non-specific and specific agents to be tested were added to the ganglion compartment and progesterone release was measured. $\mathrm{KCl}$ (56 mM) was used as a non-specific depolarising stimulus (Koh \& Hille 1997). The adrenergic agents used were NE as adrenergic agonist, Prop as $\beta$ antagonist and $\mathrm{Ph}$ as $\alpha$ antagonist. The different substances were dissolved in equal concentrations $\left(10^{-6} \mathrm{M}\right)$ and volumes $(2 \mathrm{ml})$ of Krebs-Ringer solution plus ascorbic acid.

The samples of liquid from the ovarian compartment were maintained at $-20{ }^{\circ} \mathrm{C}$ until determination of progesterone by radioimmunoasssay (RIA). The results are expressed as ng progesterone/mg ovarian tissue against the time of incubation. Corresponding corrections were made in all cases, taking into consideration the volume extracted in each test period.

\section{Luteal cell dispersion of ovaries from pregnant rats}

Luteal cells from pregnant rats were isolated as described previously (Carrizo et al. 1994, Tellería et al. 1994). The procedure was performed between 0900 and $1000 \mathrm{~h}$. Briefly, ovaries from rats decapitated on day 15 of pregnancy were collected and placed in phosphate-buffered saline (PBS; pH 7•4). The corpora lutea were dissected and luteal cells were dispersed and incubated in PBS, in the presence of collagenase $(1 \mathrm{mg} / \mathrm{ml})$ and BSA (1\%) for $1 \mathrm{~h}$ at $37^{\circ} \mathrm{C}$ in a stirred waterbath (100 r.p.m.). The dispersed cells were separated by centrifugation for $5 \mathrm{~min}$ at $800 \mathrm{~g}$. The luteal cells were washed in PBS-EDTA $(1 \mathrm{mM})$ and resuspended in medium 199 containing HEPES $(10 \mathrm{mM})$. Cell incubation was performed at a final concentration of $3 \times 10^{5}$ viable cells $/ \mathrm{ml}$ in medium 199 at $37^{\circ} \mathrm{C}$ under an atmosphere of $95 \%$ air and $5 \% \mathrm{CO}_{2}$ for $4 \mathrm{~h}$.

Iso was dissolved in medium 199 and added in a volume of $10 \mu \mathrm{l}$ to make a final concentration of $10^{-6} \mathrm{M}$. At the end of the incubation period, cells were harvested and the media were frozen at $-20{ }^{\circ} \mathrm{C}$ until the measurement of the progesterone content by RIA.

The results are expressed as progesterone $(\mathrm{ng} / \mathrm{ml}$ per $3 \times 10^{5}$ cells per $4 \mathrm{~h}$ ).

\section{Coeliac ganglion-SON-ovary system incubations with $\mathrm{LH}$}

The coeliac ganglion-SON-ovary system was also used to study some neuroendocrine aspects at peripheral levels. The values of progesterone release obtained when ovine LH was added ( $50 \mathrm{ng} / \mathrm{ml}$ in incubation buffer) to the ovarian compartment and incubation medium plus ascorbic acid to the ganglion compartment were considered to be basal (control-LH group). Those groups in which LH was not present in the ovary were considered to be controls. The experimental groups were those in which LH was present in the ovarian compartment and the adrenergic agents (NE, Prop or $\mathrm{Ph}$ ) in the ganglion compartment. The levels of progesterone released in the ovarian compartment were determined by RIA. 
Progesterone assay

Progesterone was measured by RIA using antiserum raised against progesterone-11-BSA conjugate in rabbits, provided by Dr R P Deis (Laboratorio de Reproducción y Lactancia, Mendoza, Argentina). The sensitivity, variability and cross-reaction of this RIA has been reported previously (Bussmann \& Deis 1979, Tellería et al. 1994). The sensitivity of the assay was less than $5 \mathrm{ng} / \mathrm{ml}$ serum and the inter and intra-assay coefficients of variation were less than 10\%. This assay has been validated previously (Bussmann \& Deis 1979, Donoso 1988).

\section{Statistical analysis}

Results are presented as means \pm S.E.M. in each group of six to eight rats. Differences between two groups were analysed with Student's t-test. Analysis of variance (ANOVA I), followed by Duncan's multiple range test was used for several comparisons. A value of $P<0 \cdot 05$ was considered statistically significant (Snedecor \& Cochran 1976).

\section{Results}

Coeliac ganglion-SON-ovary system: effect of the addition of $\mathrm{KCl}$ to the ganglion compartment on progesterone release by the ovary on day 15 of pregnancy

$\mathrm{KCl}$ is considered to be a non-specific stimulating agent on the preganglionic nerve fibres. When $\mathrm{KCl}(56 \mathrm{mM})$ was added to the ganglion compartment, the progesterone released by the ovary significantly decreased in comparison with the control at all times studied (Fig. 2).

Effect of the addition of adrenergic agents to the ganglion compartment on ovarian release of progesterone on day 15 of pregnancy

The addition of adrenergic agents on the coeliac ganglion led to significant variations in ovarian progesterone release at all times studied. When the stimulation was carried out with NE or Prop, progesterone secretion increased significantly as compared with the control $(P<0 \cdot 01$ and $P<0 \cdot 05$ respectively), while $\mathrm{Ph}$ induced a significant decrease in the release of progesterone, compared with the control $(P<0 \cdot 05)$ (Fig. 3).

\section{Effect of Iso on progesterone secretion by incubated luteal cells}

Luteal cells from the corpus luteum of rats on day 15 of pregnancy were incubated. The incubation was performed in the absence (control) and the presence of Iso (control+Iso), at a final concentration of $10^{-6} \mathrm{M}$, in the

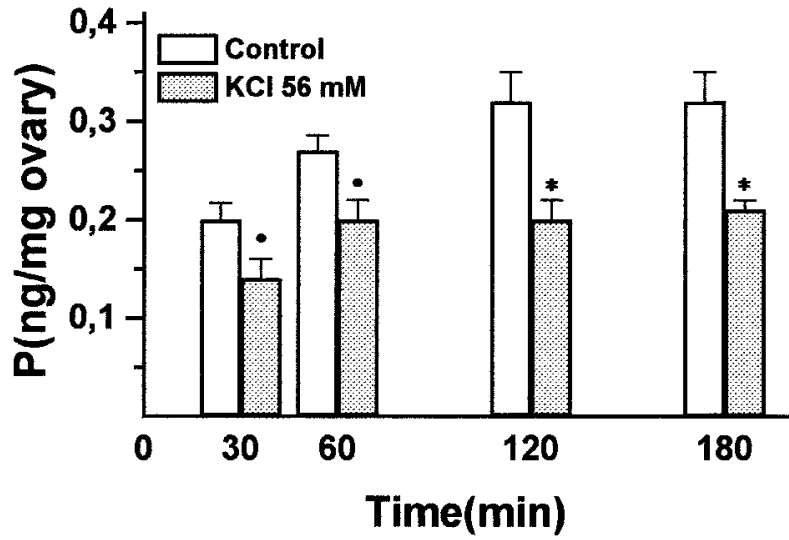

Figure 2 Effect of $\mathrm{KCl}(56 \mathrm{mM})$ added to the ganglion on progesterone $(\mathrm{P})$ release by the ovary in the coeliac ganglionSON-ovary system, obtained from rats on day 15 of pregnancy. The system was incubated in Krebs-Ringer solution at $37^{\circ} \mathrm{C}$ in an atmosphere of $95 \% \mathrm{O}_{2}-5 \% \mathrm{CO}_{2}$ for $180 \mathrm{~min}$. Ascorbic acid $(0.1 \mathrm{mg} / \mathrm{ml}$ in Krebs-Ringer) without (Control) and with $\mathrm{KCl}$ $(56 \mathrm{mM})$ was added to the ganglion compartment. Values are the means \pm S.E.M. from six to eight animals per experimental group. ${ }^{*} P<0.01, \bullet P<0.05$ compared with the control group (Student's $t$-test).

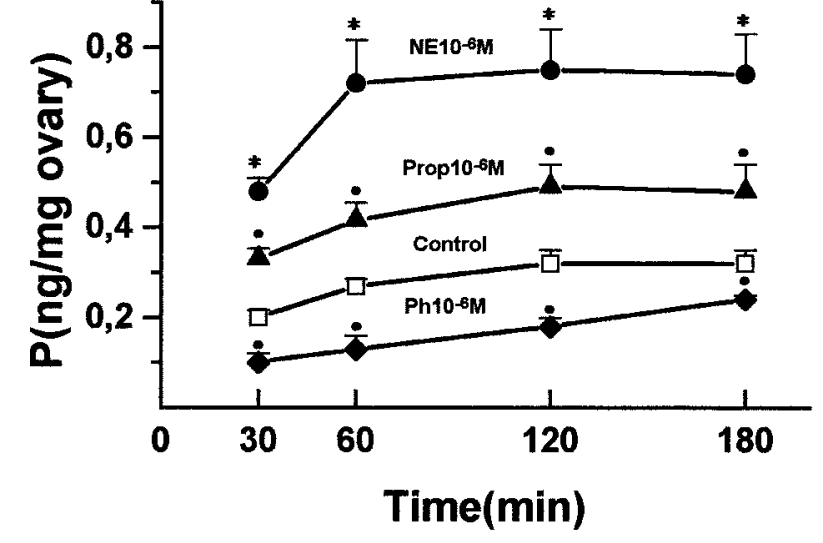

Figure 3 Effect of agonist and antagonist adrenergic agents in the ganglion on ovarian progesterone $(\mathrm{P})$ release in the coeliac ganglion-SON-ovary system obtained from rats on day 15 of pregnancy. The system was incubated in Krebs-Ringer solution at $37{ }^{\circ} \mathrm{C}$ in an atmosphere of $95 \% \mathrm{O}_{2}-5 \% \mathrm{CO}_{2}$ for $180 \mathrm{~min}$. Ascorbic acid $(0 \cdot 1 \mathrm{mg} / \mathrm{ml}$ in Krebs-Ringer) without (Control) and with adrenergic agents at a concentration of $10^{-6} \mathrm{M}$ was added to the ganglion compartment. Values are the means \pm S.E.M. from six to eight animals per experimental group. ${ }^{*} P<0 \cdot 01, \bullet P<0 \cdot 05$ compared with the control group (ANOVA I-Duncan's multiple range test).

incubation medium. Figure 4 shows that the presence of the adrenergic agonist did not modify the progesterone release from incubated luteal cells in relation to the control values. 


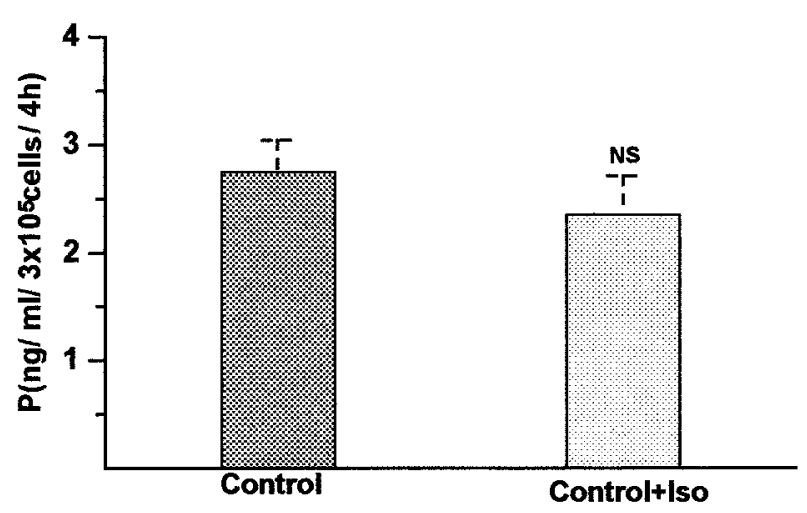

Figure 4 Progesterone $(\mathrm{P})$ production by luteal cells from 15-day pregnant rats in the absence (Control) or presence of Iso $\left(10^{-6} \mathrm{M}\right.$; Control+Iso) in the incubation medium. Cells were incubated at $37{ }^{\circ} \mathrm{C}$ under an atmosphere of $95 \% \mathrm{O}_{2}-5 \% \mathrm{CO}_{2}$ for $4 \mathrm{~h}$. Values are the means \pm S.E.M. of quadruplicate determinations of three different experiments. NS, not significant compared with the control group (Student's t-test).

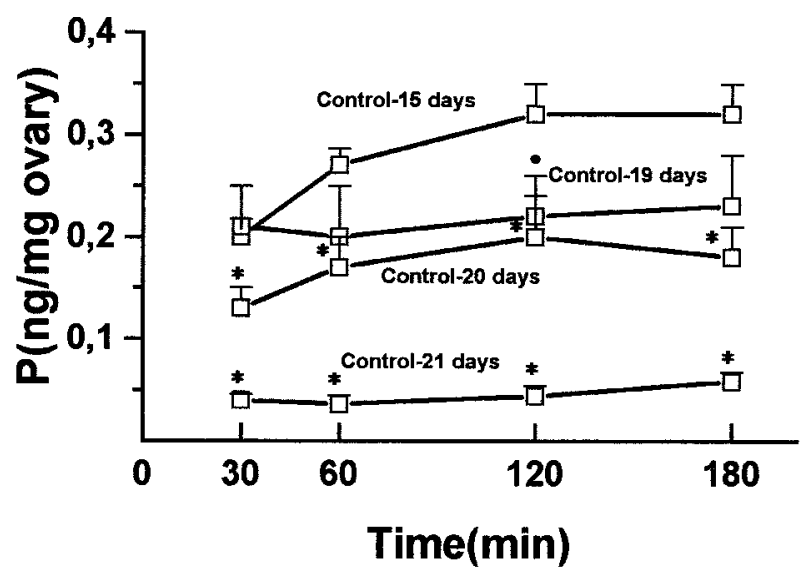

Figure 5 Progesterone $(\mathrm{P})$ release by the ovary in the coeliac ganglion-SON-ovary system obtained from rats on days 15 , 19,20 and 21 of pregnancy. The systems were incubated in Krebs-Ringer solution plus ascorbic acid $(0 \cdot 1 \mathrm{mg} / \mathrm{ml}$ in Krebs-Ringer) in the ganglion compartment at $37^{\circ} \mathrm{C}$ in an atmosphere of $95 \% \mathrm{O}_{2}-5 \% \mathrm{CO}_{2}$ for $180 \mathrm{~min}$. Values are the means \pm S.E.M. from six to eight animals per experimental group. ${ }^{*} P<0 \cdot 01, \bullet P<0 \cdot 05$ compared with control-15 days groups (ANOVA I-Duncan's multiple range test).

Study of the existence of autonomic ganglionic tone in the coeliac ganglion-SON-ovary system

To verify that the coeliac ganglion-SON-ovary system is a functional entity with its own autonomic tone, the control values of progesterone release on the different days of pregnancy studied (Fig. 5) were analysed. The highest values were those on day 15 of pregnancy and, in comparison with this day, the levels diminished as the end of pregnancy approached. On day 19, only one significant decrease in relation to day 15 was observed, at $120 \mathrm{~min}$ of incubation $(0.22 \pm 0.04$ compared with $0.32 \pm 0.03 \mathrm{ng} /$ mg ovary, $P<0 \cdot 05)$, whereas on days 20 and 21 a significant decrease compared with day 15 was observed, at all times studied $(P<0 \cdot 01)$.

Effect of the addition of adrenergic agents to the ganglion compartment on release of ovarian progesterone at the end of pregnancy

The same coeliac ganglion-SON-ovary experimental scheme used on day 15 was used to investigate whether the adrenergic action on the release of ovarian progesterone was still significant at the end of pregnancy. The results obtained showed that on day $19 \mathrm{NE}$ increased the release of progesterone at all times studied in relation to the control $(P<0 \cdot 05)$. Prop caused a significant decrease at 30 and $120 \mathrm{~min}(0 \cdot 10 \pm 0.02$ compared with $0.21 \pm 0.04 \mathrm{ng} /$ mg ovary, $P<0.01$ and $0.15 \pm 0.03$ compared with $0.22 \pm 0.04 \mathrm{ng} / \mathrm{mg}$ ovary, $P<0.05)$ while $\mathrm{Ph}$ decreased progesterone release at all times studied compared with the control $(P<0 \cdot 01)$ (Fig. 6A).

On day 20 , the three agents studied significantly decreased the levels of progesterone at all times studied (Fig. 6B), whereas on day 21 no significant differences were observed as compared with the control (Fig. 6C).

Effect of the addition of $\mathrm{LH}$ to the ovarian compartment on the release of progesterone on day 15 of pregnancy

The presence of the gonadotrophin in the ovarian compartment did not modify the release of progesterone in relation to the control at any of the times studied (Fig. 7). All the adrenergic agents studied caused a decrease in the ovarian response as compared with control-LH when they were added in the ganglion compartment and LH was added in the ovarian compartment at all times studied (Fig. 8). This decrease was also observed when the presence of NE or Prop in the ganglionic compartment together with $\mathrm{LH}$ in the ovarian compartment was compared with the sole stimulation of either NE or Prop in the coeliac ganglion. On the other hand, $\mathrm{Ph}$ maintained its inhibitory effect with and without LH. The above-described results are compared in Table 1, in which the results of Figs 3, 7 and 8 have been repeated for clarity.

\section{Discussion}

Studies on the participation of the SON in ovarian function have been performed on prepuberal, peripuberal, cyclic adult and pseudopregnant rats (Condon \& Black 1976, Harwood et al. 1980, Adashi \& Hsueh 1981, Jordan 1981, Aguado et al. 1982, Aguado \& Ojeda 1984a,b, Norjavaara et al. 1984, 1989, Sosa et al. 2000). However, little attention has been paid to this issue in pregnant rats (Burden 1985). It is to be noted that progesterone release 


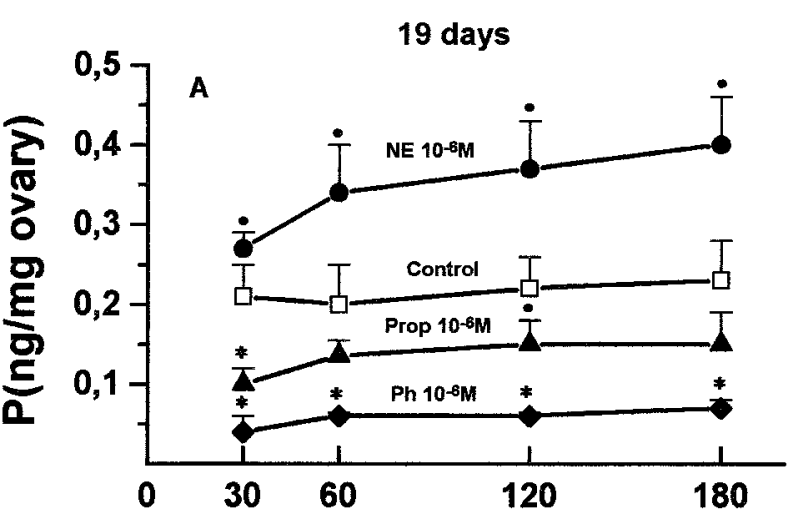

\section{Time(min)}
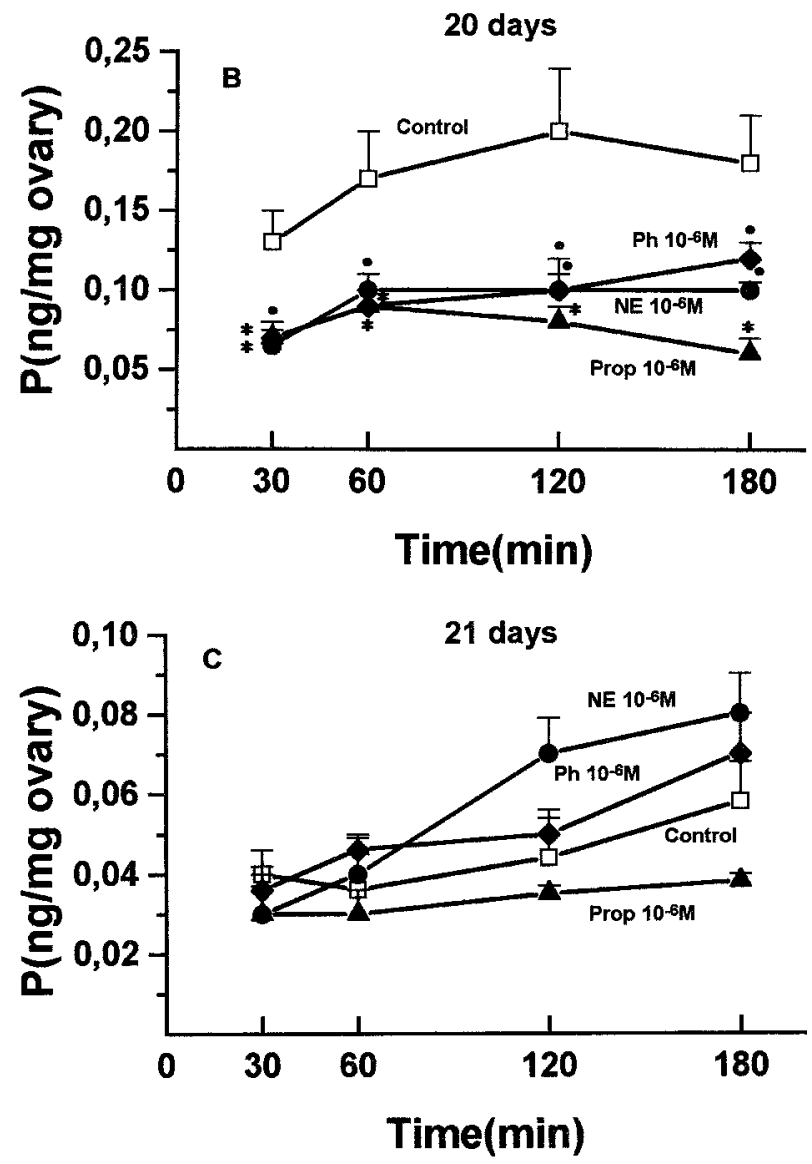

Figure 6 Effect of agonist and antagonist adrenergic agents in the ganglion on ovarian progesterone $(\mathrm{P})$ release in the coeliac ganglion-SON-ovary system obtained from rats on days 19 (A), 20 (B) and $21(\mathrm{C})$ of pregnancy. The systems were incubated in Krebs-Ringer solution at $37{ }^{\circ} \mathrm{C}$ in an atmosphere of $95 \% \mathrm{O}_{2}-5 \%$ $\mathrm{CO}_{2}$ for $180 \mathrm{~min}$. Ascorbic acid $(0.1 \mathrm{mg} / \mathrm{ml}$ in Krebs-Ringer) without (Control) and with adrenergic agents at a concentration of $10^{-6} \mathrm{M}$ was added to the ganglion compartment. Values are the means \pm S.E.M. from six to eight animals per experimental group. ${ }^{*} P<0.01, \bullet P<0.05$ compared with the respective control groups (ANOVA I-Duncan's multiple range test).

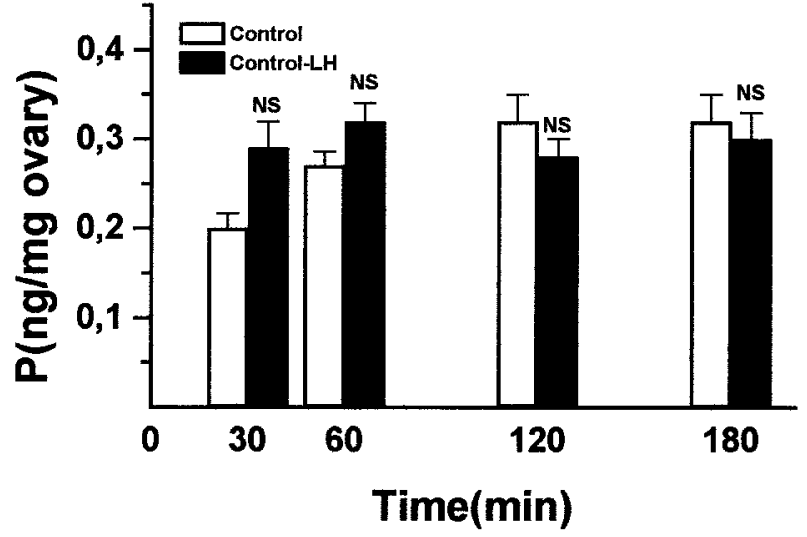

Figure 7 Progesterone $(\mathrm{P})$ release by the ovary in the coeliac ganglion-SON-Ovary system obtained from rats on day 15 of pregnancy with or without $\mathrm{LH}(50 \mathrm{ng} / \mathrm{ml})$ in the ovarian compartment. The system was incubated in Krebs-Ringer solution, plus ascorbic acid in the ganglionic compartment, at $37^{\circ} \mathrm{C}$ in an atmosphere of $95 \% \mathrm{O}_{2}-5 \% \mathrm{CO}_{2}$ for $180 \mathrm{~min}$ and in the ovarian compartment in the absence (Control) or presence of $\mathrm{LH}$ (Control-LH). Values are the means \pm S.E.M. from six to eight animals per experimental group. NS, not significant compared with the control group (Student's t-test).

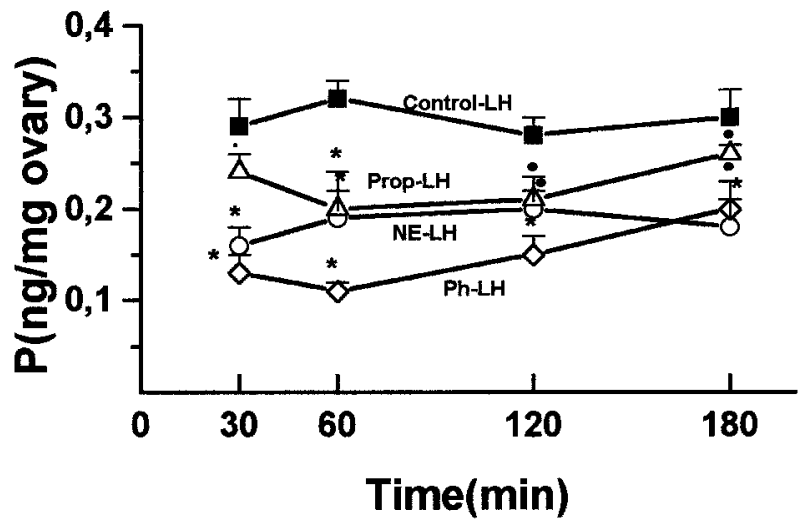

Figure 8 Effect of adrenergic agents in the ganglion and $\mathrm{LH}$ $(50 \mathrm{ng} / \mathrm{ml})$ in the ovary on the release of ovarian progesterone $(\mathrm{P})$, using the coeliac ganglion-SON-ovary system obtained from rats on day 15 of pregnancy. The system was incubated in Krebs-Ringer solution at $37{ }^{\circ} \mathrm{C}$ in an atmosphere of $95 \% \mathrm{O}_{2}-5 \%$ $\mathrm{CO}_{2}$ for $180 \mathrm{~min}$. LH was added to the ovarian compartment and ascorbic acid $(0 \cdot 1 \mathrm{mg} / \mathrm{ml}$ in Krebs-Ringer) without (Control-LH) and with adrenergic agents $\left(10^{-6} \mathrm{M}\right)$ added to the ganglion compartment. Values are the means \pm S.E.M. from six to eight animals per experimental group. ${ }^{*} P<0 \cdot 01, \bullet P<0.05$ compared with the Control-LH group (ANOVA I-Duncan's multiple range test).

has been shown to be one of the processes most sensitive to neural regulation (Aguado et al. 1982). The corpus luteum is the main source of progesterone (Gibori 1993) and so we have studied the neural effect on the ovary during pregnancy, where the corpus luteum is the predominant structure. 
Table 1 Progesterone release by the ovary at different times in a coeliac ganglion-SON-ovary system obtained from rats on day 15 of pregnancy. The system was incubated in Krebs-Ringer solution plus ascorbic acid in the ganglionic compartment, at $37^{\circ} \mathrm{C}$ in an atmosphere of $95 \% \mathrm{O}_{2}-5 \% \mathrm{CO}_{2}$ for $180 \mathrm{~min}$, in the absence (Control) or presence of $\mathrm{LH}(50 \mathrm{ng} / \mathrm{ml})(\mathrm{Control}-\mathrm{LH})$ in the ovarian compartment. The system was also incubated with ascorbic acid $\left(0 \cdot 1 \mathrm{mg} / \mathrm{ml}\right.$ in Krebs-Ringer) and adrenergic agents $\left(10^{-6} \mathrm{M}\right)$ in the ganglionic compartment and without LH in the ovarian compartment (NE or Prop or Ph). The system was also incubated with ascorbic acid $\left(0.1 \mathrm{mg} / \mathrm{ml}\right.$ in Krebs-Ringer) and adrenergic agents $\left(10^{-6} \mathrm{M}\right)$ in the ganglionic compartment and with $\mathrm{LH}$ in the ovarian compartment. Values are the means \pm S.E.M. from six to eight animals per experimental group

Progesterone (ng/mg ovary)

\begin{tabular}{|c|c|c|c|c|c|c|c|c|}
\hline & Control & Control-LH & $\mathrm{NE}$ & LH-NE & Prop & LH-Prop & $\mathrm{Ph}$ & $\mathrm{LH}-\mathrm{Ph}$ \\
\hline \multicolumn{9}{|c|}{$\begin{array}{l}\text { Time } \\
(\min )\end{array}$} \\
\hline 30 & $0 \cdot 20 \pm 0 \cdot 017$ & $0 \cdot 29 \pm 0.03$ & $0.48 \pm 0.03$ & $0.16 \pm 0.02 *$ & $0 \cdot 33 \pm 0 \cdot 024$ & $0.24 \pm 0.04$ * & $0 \cdot 1 \pm 0 \cdot 02$ & $0 \cdot 13 \pm 0.02^{\mathrm{NS}}$ \\
\hline 60 & $0 \cdot 27 \pm 0 \cdot 016$ & $0.32 \pm 0.02$ & $0.72 \pm 0.096$ & $0 \cdot 19 \pm 0.03^{*}$ & $0 \cdot 415 \pm 0 \cdot 04$ & $0 \cdot 20 \pm 0 \cdot 04^{*}$ & $0 \cdot 13 \pm 0.03$ & $0 \cdot 11 \pm 0 \cdot 01^{\mathrm{NS}}$ \\
\hline 120 & $0 \cdot 32 \pm 0 \cdot 03$ & $0.25 \pm 0.03$ & $0.75 \pm 0.09$ & $0 \cdot 2 \pm 0.03^{*}$ & $0.49 \pm 0.05$ & $0 \cdot 21 \pm 0.03^{*}$ & $0 \cdot 18 \pm 0 \cdot 02$ & $0 \cdot 15 \pm 0 \cdot 02^{\mathrm{NS}}$ \\
\hline 180 & $0.32 \pm 0.03$ & $0 \cdot 30 \pm 0.03$ & $0.74 \pm 0.09$ & $0 \cdot 18 \pm 0.03^{*}$ & $0 \cdot 48 \pm 0.06$ & $0 \cdot 28 \pm 0 \cdot 04^{*}$ & $0 \cdot 24 \pm 0.03$ & $0 \cdot 2 \pm 0.03^{\mathrm{NS}}$ \\
\hline
\end{tabular}

${ }^{*} P<0 \cdot 01$, NE compared with NE-LH; $P<0 \cdot 01$, Prop compared with Prop-LH; NS, not significant, Ph compared with Ph-LH at all times analysed (ANOVA I-Duncan's multiple range test). Other statistical comparisons are made in Figs 3, 7 and 8.

The present study provides evidence that the response of the ovary to a neural stimulus varies in the different stages of pregnancy studied. Additionally, the results indicate that there is an inter-relationship between the adrenergic ganglionic effect and the endocrine action of LH on the ovary. These results were obtained using the coeliac ganglion-SON-ovary system previously standardised in our laboratory for the oestrous cycle (Sosa et al. 2000). The system characterisation was performed on day 15 of pregnancy, since this is the time of maximum activity of the corpus luteum (Uchida et al. 1970) and therefore it was assumed that the sensitivity of the system to neural inputs would be increased on this day. Addition of a moderate concentration $(56 \mathrm{mM})$ of $\mathrm{KCl}$ (Koh \& Hille 1997) to the ganglionic compartment on this day caused a significant decrease in progesterone release at all times, in comparison with the basal level. Since $\mathrm{KCl}$ is a nonspecific depolarising agent of ganglionic cells, it is very probable that the release of several neurotransmitters was favoured, thus leading to an inhibitory effect on ovarian function. The ovarian response observed demonstrated the functional integrity of the coeliac ganglion-SONovary system. In addition, the ganglion did not exhibit microscopic changes when studied at the end of each experiment, which also supports the viability of the system.

Even though acetylcholine is a typical preganglionic sympathetic neurotransmitter (Sarper 1995), the coelic ganglion was stimulated with adrenergic agents once the characterisation had been performed. This choice was based on the fact that the coeliac ganglion is innervated by fibres of an adrenergic nature which come from the medulla and by other preaortic ganglia (Sarper et al. 1976, Messenger \& Furness 1992). In addition, it is to be noted that $\alpha$ and $\beta$ adrenergic receptors have been detected in the superior cervical ganglion and other ganglia (Pinto et al. 1991, Shivachar \& Eikenburg 1999). The effect of adrenergic ganglionic stimulation on ovarian progesterone release has also been demonstrated in our laboratory using the same integrated system (Sosa et al. 2000).

The addition of NE to the ganglion compartment on day 15 of pregnancy showed a strong increase in the release of progesterone from the ovary. Progesterone secretion was also stimulated by Prop while $\mathrm{Ph}$ diminished it significantly. When luteal cells from corpora lutea of rats on day 15 of pregnancy were incubated in the presence of $10^{-6} \mathrm{M}$ Iso, an adrenergic $\beta$ agonist, no variations were observed in progesterone production. This demonstrates poor sensitivity of luteal cells to direct adrenergic stimulation, in spite of the presence of $\beta$ receptors in the membranes of the ovarian cells (Harwood et al. 1979).

The differences observed in the results obtained with the two experimental schemes used demonstrates that the integrity of the system is necessary for ovarian response to neural action. This indicates that the system used here has the advantages of preserving intraovarian factors and keeping SON innervation intact.

On the other hand, the existence of ganglionic tone under our experimental conditions was confirmed by analysing the variations of the basal levels of progesterone in the different stages of pregnancy studied. The highest values corresponded to day 15 of pregnancy and, as expected, progesterone release decreased as pregnancy advanced. The ganglionic tone allows the use of antagonists in the ganglion without simultaneous addition of the corresponding agonist.

Having demonstrated the action of innervation on day 15 of pregnancy, the same coeliac ganglion-SON-ovary system was used to analyse its action during the physiological luteolysis occurring at the end of pregnancy on days 19, 20 and 21 (Hurwitz \& Adashi 1993). On day 19, NE added to the ganglion compartment significantly increased progesterone release while Prop and $\mathrm{Ph}$ decreased it. It might be inferred that the effect of $\mathrm{NE}$ on progesterone 
release would take place through $\alpha$ or $\beta$ adrenergic receptors, but our experimental scheme does not allow us to discern whether they are pre- or post-ganglionic. The interpretation of these results is further complicated by the presence of interneurones with peptidergic and dopaminergic neurotransmitters, among others (Mentel et al. 1976, Polónyi et al. 1982, Matthews 1989).

On day 20, a significant reduction of progesterone was observed with both NE and its antagonists, while on day 21 no significant effects were detected with any of the adrenergic agents studied. This therefore suggests that the steroidogenic response to neural action gradually decreases with the establisment of physiological luteolysis at the end of gestation (Hurwitz \& Adashi 1993).

In the present work, some neuroendocrine aspects were also studied at the peripheral level. Other authors have observed an inter-relationship between catecholamines and LH in cultures of luteal cells of rats at other physiological stages (Harwood et al. 1980, Jena \& Abramowitz 1989).

The addition of LH to the ovary on day 15 of pregnancy in the system under study did not lead to any variations in the release of progesterone. This was to be expected, since LH levels exhibit very low values on day 15 (Morishige et al. 1973, Taya \& Greenwald 1981). However, when the addition of LH to the ovary was accompanied by the addition of $\mathrm{NE}$, Prop or $\mathrm{Ph}$ to the ganglionic compartment, progesterone production fell. From Table 1 it can be inferred that addition of $\mathrm{LH}$ to the ovary decreases the augmented progesterone release provoked by the addition of NE or Prop to the ganglion, while it does not modify the ovarian response provoked by the addition of $\mathrm{Ph}$ to the ganglion.

Overall, it can be concluded that the coeliac ganglionSON-ovary system used here provides a good resemblance of in vivo conditions, particularly of ovarian innervation. As shown, at the time of the highest production of progesterone (day 15 of pregnancy), NE produces a noticeable increase of the analysed steroid, which supports its role in the maintenance of pregnancy. This neural influence is maintained until day 19 and decreases as the end of pregnancy approaches, helping the conditions of birth. In other words, the neural action adds up to the other factors involved in the reproductive phenomenon. The results obtained here may represent an advance in the knowledge of the role of neural control in the ovary's function during pregnancy. Furthermore, they might help to further understand certain pathologic states of reproduction that cannot be explained by purely hormonal causes.

\section{Acknowledgements}

This work was supported by Grant 3711/92 from CONICET (Consejo Nacional de Investigaciones Cientí ficas y Técnicas, Argentina) and by Grant 9302 from
Universidad Nacional de San Luis, Argentina. L A is a career researcher at CONICET. The authors are very grateful to Dr R P Deis who provided the progesterone antiserum. We acknowledge Luis Villegas and Santiago Ojeda for their technical assistance.

\section{References}

Adashi EY \& Hsueh AJ 1981 Stimulation of $\beta_{2}$-adrenergic responsiveness by follicle-stimulating hormone in rat granulosa cells in vitro and in vivo. Endocrinology 108 2170-2178.

Aguado LI \& Ojeda SR 1984a Ovarian adrenergic nerves play a role in maintaining preovulatory steroid secretion. Endocrinology 114 1944-1946.

Aguado LI \& Ojeda SR $1984 b$ Prepubertal ovarian function is finely regulated by direct adrenergic influences: role of noradrenergic innervation. Endocrinology 114 1845-1853.

Aguado LI, Petrovic SL \& Ojeda SR 1982 Ovarian adrenergic receptors during the onset of puberty: characterization, distribution and coupling to steroidogenic responses. Endocrinology $\mathbf{1 1 0}$ $1124-1132$

Behrman HR, Preston SL, Aten RF, Rinaudo P \& Zreik TG 1996 Hormone induction of ascorbic acid transport in immature granulosa cells. Endocrinology 137 4316-4321.

Burden HW 1985 The adrenergic innervation of mammalian ovaries. In Catecholamines as Hormone Regulators, pp 261-265. Eds N Ben-Jonathan, J Bahr \& R Weiner. New York: Raven Press.

Burden HW \& Lawrence IE Jr 1977 The effects of denervation on the localization of delta 5-3 beta-hydroxysteroid dehydrogenase activity in the rat ovary during pregnancy. Acta Anatomica 97 286-290.

Bussmann LE \& Deis RP 1979 Studies concerning the hormonal induction of lactogenesis by prostaglandin $\mathrm{F}_{2} \alpha$ in pregnant rats. Journal of Steroid Biochemistry and Molecular Biology 11 1485-1489.

Carrizo DG, Rastrilla AM, Tellería CM \& Aguado LI 1994 Androstenedione stimulates progesterone production in corpora lutea of pregnant rats: an effect not mediated by oestrogen. Journal of Steroid Biochemistry and Molecular Biology 51 191-197.

Coleman AJ, Paterson DS \& Somerville AR 1979 The beta adrenergic receptor of the corpus luteum membranes. Biochemical Pharmacology 28 1003-1010.

Condon WA \& Black DL 1976 Catecholamine-induced stimulation of progesterone by the bovine corpus luteum in vitro. Biology of Reproduction 15 573-578.

Dalsgaard CJ, Hökfelt T, Schultzberg M, Lundberg JM, Terenius L, Dockray GJ \& Goldstein M 1983 Origin of peptide-containing fibers in the inferior mesenteric ganglion of the guinea-pig: immunohistochemical studies with antisera to substance P, enkephalin, vasoactive intestinal polypeptide, cholecystokinin and bombesin. Neuroscience 9 191-211.

De Bortoli MA, Garraza MH \& Aguado LI 1998 Adrenergic intracerebroventricular stimulation affects progesterone concentration in the ovarian vein of the rat: participation of the superior ovarian nerve. Journal of Endocrinology 159 61-68.

Dees WL, Ahmed CE \& Ojeda SR 1986 Substance P and vasoactive intestinal peptide containing fibers reach the ovary by independent routes. Endocrinology 119 638-645.

Dhariwal KR, Washko P, Hartzell WO \& Levine M 1989 Ascorbic acid within chromaffin granules. in situ kinetics of norepinephrine biosynthesis. Journal of Biological Chemistry 264 15404-15409.

Dissen GA, Les Dees WL \& Ojeda SR 1993 Neural and neurotrophic control of ovarian development. In The Ovary, pp 1-18. Eds EY Adashi \& CK Leung. New York: Raven Press.

Donoso AO 1988 Luteinizing hormone release induced by noradrenaline after administration of drugs that increase 
hypothalamic GABA levels. Acta Physiologica, Pharmacologica et Therapeutica Latinoamerica 38 11-18.

Erdö SL, Varga B \& Horvath E 1985 Effect of local GABA administration on rat ovarian blood flow and on progesterone and estradiol secretion. European Journal of Pharmacology 111 397-404.

Ferruz J, Ahmed CE, Ojeda SR \& Lara HE 1992 Norepinephrine release in the immature ovary is regulated by autoreceptors and neuropeptide-Y. Endocrinology 130 1345-1351.

Gerendai I, Csaba Zs, Voko Z \& Csernus V 1995 Involvement of a direct neural mechanism in the control of gonadal functions. Journal of Steroid Biochemistry and Molecular Biology 53 299-305.

Gibori G 1993 The corpus luteum of pregnancy. In The Ovary, pp 261-317. Eds EY Adashi \& PCK Leung. New York: Raven Press.

Godkin JD, Black DL \& Duby RT 1977 Stimulation of cyclic AMP and progesterone synthesis by $\mathrm{LH}, \mathrm{PGE}_{2}$ and isoproterenol in the bovine CL in vitro. Biology of Reproduction 17 514-518.

Häppölä O, Päivä rinta H, Soinila S, Wu JY \& Panula P 1987 Localization of L-glutamate decarboxylase and Gaba transaminase immunoreactivity in the sympathetic ganglia of the ra. Neuroscience 21 271-281.

Harwood JP, Dufau ML \& Catt KJ 1979 Differing specificities in the desensitization of ovarian adenylate cyclase by epinephrine and human chorionic gonadotropin. Molecular Pharmacology 15 439-445.

Harwood JP, Richert ND, Dufau ML \& Catt KJ 1980 Gonadotropin-induced desensitization of epinephrine action in the luteinized rat ovary. Endocrinology 107 280-288.

Hsueh AJW \& Erickson GF 1979 Extrapituitary action of gonadotropin releasing hormone: direct inhibition of ovarian steroidogenesis. Science $204845-855$.

Hsueh AJW \& Jones PBC 1981 Extrapituitary actions of gonadotropin-releasing hormone. Endocrine Reviews 2 437-461.

Hurwitz A \& Adashi EY 1993 Ovarian follicular atresia as an Apoptotic process. In The Ovary, pp 473-485. Eds EY Adashi \& PCK Leung. New York: Raven Press.

Jan LY \& Jan YN 1981 Role of an LHRH-like peptide as a neurotransmitter in sympathetic ganglia of the frog. Federation Proceedings 40 2560-2564.

Jan LY \& Jan YN 1982 Peptidergic transmission in sympathetic ganglia of the frog. Journal of Physiology 327 219-246.

Jan YN \& Jan LY 1983 Coexistence and corelease of cholinergic and peptidergic transmitters in frog sympathetic ganglia. Federation Proceedings 42 2929-2933.

Jena BP \& Abramowitz J 1989 Catecholamine-induced heterologous desensitization of rabbit luteal adenylyl cyclase: loss of luteinizing hormone responsiveness is associated with impaired G-protein function. Endocrinology 124 1942-1948.

Jordan AW 1981 Changes in ovarian beta adrenergic receptors during the estrous cycle of the rat. Biology of Reproduction 24 245-248.

Kaleczyc J, Majewski M, Kakomy M \& Sienkiewics V 1995 Occurrence and coexistence of some neuropeptides in nerve fibers supplying the bovine ovary and its extrinsic blood vessels. Folia Histochemica et Cytobiologica 33 163-169.

Karhula T, Häppölä O, Joh T \& Wu JY 1988 Localization of L-glutamate decarboxylase immunoreactivity in the major pelvic and in the coeliac-superior mesenteric ganglion complex of the rat. Histochemistry 90 255-260.

Kawakami M, Kubo K, Uemura T, Nagase M \& Hayashi R 1981 Involvement of ovarian innervation in steroid secretion. Endocrinology 109 136-145.

Klein CM \& Burden HW 1988 Anatomical localization of afferent and postganglionic sympathetic neurons innervating the rat ovary. Neuroscience Letters 85 217-222.

Koh DS \& Hille B 1997 Modulation by neurotransmitters of catecholamine secretion from sympathetic ganglion neurons detected by amperometry. PNAS 94 1506-1511.

Lara HE, Mc Donald JK \& Ojeda SR 1990a Involvement of nerve growth factor in female sexual development. Endocrinology 126 364-375.
Lara HE, McDonald JK, Ahmed CE \& Ojeda SR $1990 b$

Guanethidine-mediated destruction of ovarian sympathetic nerves disrupts ovarian development and function in rats. Endocrinology 127 2199-2209.

Lascar G, Eugene D \& Taxi J 1996 Synaptic organization of amphibian sympathetic ganglia. Microscopy Research and Technique 35 $157-178$

Lawrence IE Jr \& Burden HW 1976 The autonomic innervation of the interstitial gland of the rat ovary during pregnancy. American Journal of Anatomy 147 81-94.

Lawrence IE Jr \& Burden HW 1980 The origin of the extrinsic adrenergic innervation to the ovary. Anatomical Record 196 $51-59$.

Massa HM \& Bruce NW 1994 Effects of noradrenaline on blood flow, progesterone secretion and oxygen consumption in the intact ovary of rats on day 16 of pregnancy. Journal of Reproduction and Fertility 101 605-610.

Matthews MR 1989 Small intensely fluorescent cells and the paraneuron concept. Journal of Electron Microscopy Technique 12 408-416.

Mentel J, Kapeller K, Gombos A \& Polónyi J 1976 Relationship of blood vessels to small intensely fluorescent cells in the autonomic ganglion. Zeitschrift fûr Mikroskopisch-Anatomische Forschung $\mathbf{9 0}$ 571-575.

Messenger JP \& Furness JB 1992 Distribution of enteric nerve cells that project to the coeliac ganglion of the guinea-pig. Cell and Tissue Research 269 119-132.

Morishige WK, Pepe GJ \& Rothchild I 1973 Serum luteinizing hormone, prolactin and progesterone levels during pregnancy in the rat. Endocrinology 92 1527-1530.

Norjavaara E, Selstam G \& Ahren K 1982 Catecholamine stimulation of cyclic AMP and progesterone production in rat corpora lutea of different ages. Acta Endocrinologica $100613-622$.

Norjavaara E, Rosberg S, Gafvels M \& Selstam G 1984 Betaadrenergic receptor concentration in corpora lutea of different ages obtained from pregnant mare serum gonadotropin-treated rats. Endocrinology $1142154-2159$.

Norjavaara E, Rosberg S, Gafvels M, Boberg BM \& Selstam G 1989 Beta adrenergic receptor concentration and subtype in the corpus luteum of the adult pseudopregnant rat. Journal of Reproduction and Fertility 86 567-575.

Ojeda SR \& Aguado LI 1985 Adrenergic control of the prepubertal ovary: involvement of local innervation and circulating catecholamines. In Catecholamines as Hormone Regulators, pp 293-310. Eds N Ben-Jonathan, JM Bahr \& RI Weiner. New York: Raven Press.

Ojeda SR \& Lara HE 1989 Role of the sympathetic nervous system in the regulation of the ovarian function. In The Menstrual Cycle and its Disorders, pp 26-35. Eds KM Pirke, W Wuttke \& U Schweiger. Berlin: Springer-Verlag.

Pieper DR, Richards J \& Marshall J 1981 Ovarian gonadotropinreleasing hormone $(\mathrm{GnRH})$ receptors: characterization, distribution and induction by GnRH. Endocrinology 108 1148-1155.

Pinto JE, Flügge G, Viglione PN, Torda T, Nazarali AJ \& Saavedra JM 1991 Increased $\beta_{2}$ adrenoreceptors in the superior cervical ganglia of genetically hypertensive rats. Brain Research $\mathbf{5 4 2}$ $35-42$.

Polónyi J, Kapeller K \& Mráz P 1982 in vitro fine structural study of SIF cells and neurons in sympathetic ganglion after vinblastine treatment. Zeitschrift fûr Mikroskopisch-Anatomische Forschung 96 537-554.

Roche PJ, Parkington HC \& Gibson WR 1985 Pregnancy and parturition in rats after sympathetic denervation of the ovary, oviduct and utero-tubal junction. Journal of Reproduction and Fetility 75 653-661.

Sarper CB 1995 Organization of cerebral cortical afferent system in the rat hypothalamocortical projections. Journal of Neurology 237 21-46. 
Sarper CB, Loewy AD, Swanson LW \& Cowan WM 1976 Direct hypothalamo-autonomic connections. Brain Research 117 305-316.

Sejnowski TJ 1982 Peptidergic synaptic transmission in sympathetic ganglia. Federation Proceedings 13 2923-2928.

Sheela Rani CS, Ekholm C, Billig H, Magnusson C \& Hillensjö T 1983 Biphasic effect of gonadotropin releasing hormone on progestin secretion by rat granulosa cells. Biology of Reproduction 28 591-597.

Shivachar AC \& Eikenburg DC 1999 Differential effects of epinephrine and norepinephrine on cAMP response on protein expression in cultured sympathetic neurons. Journal of Pharmacology and Experimental Therapeutics 1 258-264.

Snedecor GW \& Cochram WG 1976 Statistical Methods. Ames, Iowa: Iowa State University Press.

Sosa ZY, Casais M, Rastrilla AM \& Aguado LI 2000 Adrenergic influences on coeliac ganglion affect the release of progesterone from cycling ovaries: characterisation of an in vitro system. Journal of Endocrinology 166 307-318.
Taya K \& Greenwald GS 1981 In vivo and in vitro ovarian steroidogenesis in the pregnant rat. Biology of Reproduction 25 683-691.

Tellería CM, Carrizo DG \& Deis RP 1994 Levonorgestrel inhibits luteinizing hormone estimulated progesterone production in rat luteal cells. Journal of Steroid Biochemistry and Molecular Biology $\mathbf{5 0}$ 161-166.

Uchida K, Kadowaki M, Nomura Y Miyata k \& Miyake T 1970 Relationship between ovarian progestin secretion and corpora lutea function in pregnant rats. Endocrinologia Japonica 17 499-507.

Zsolnai B, Varga B \& Horvath E 1982 Increase of ovarian progesterone secretion by $\beta_{2}$-adrenergic stimulation in oestrous rats. Acta Endocrinologica 101 268-272.

Received 24 April 2001

Accepted 14 May 2001 